${ }^{1}$ B. Belleville, ${ }^{1}$ T. Stevanovic*, ${ }^{1}$ A. Cloutier, ${ }^{2}$ A. Pizzi, ${ }^{3}$ M. Prado, ${ }^{4}$ S. Erakovic, ${ }^{5}$ P. N. Diouf, ${ }^{6}$ M. Royer.

\title{
An investigation of thermochemical changes in Canadian hardwood species during wood welding
}

${ }^{1}$ Centre de recherche sur le bois, Département des sciences du bois et de la forêt, Univ. Laval, Québec, Canada (*corresponding author : Tatjana.Stevanovic@ @sbf.ulaval.ca, $)$;

${ }^{2}$ ENSTIB-LERMAB, Univ. Henri Poincaré, Nancy 1, France

${ }^{3}$ Faculté des sciences de la vie, Univ. de Strasbourg, France);

${ }^{4}$ Faculty of technology and metallurgy, Univ. of Belgrade, Serbia;

${ }^{5}$ SEREX, Amqui, Canada, and Département des sciences du bois et de la forêt, Univ. Laval, Québec, Canada

${ }^{6}$ Centre de recherche sur le bois, Département des sciences du bois et de la forêt, Univ. Laval, Québec, Canada

\begin{abstract}
Thermochemical changes during wood-dowel welding were investigated in two Canadian hardwood species commonly used for indoor appearance applications: sugar maple (Acer saccharum) and yellow birch (Betula alleghaniensis). The original reference wood sample and the welded interface between two bonded wood pieces, a dowel and a substrate, were compared to explain differences in mechanical properties between species. Pyrolysis gas chromatography mass spectrometry (Py-GC/MS), attenuated total reflection Fourier transform infrared spectroscopy (ATR-FTIR), and X-ray photoelectron spectroscopy (XPS) were used. The gases emitted during wood welding were determined by Py-GC/MS and gas chromatography coupled with a thermal conductivity detector and a flame ionization detector (GC-TCD/FID). Results showed that thermal welding of birch and maple woods degrades hemicelluloses and affects lignin polymer through depolymerisation. Welding effectiveness is therefore directly associated with the properties of the original wood constituents, primarily lignin and carbohydrates. The lignin-related changes at the welded interface were greater for sugar maple than for yellow birch, corroborating mechanical property differences observed between the two species. The gases proportions were similar for both species and no harmful gases were detected in the smoke released during welding process.
\end{abstract}




\section{Untersuchung von thermochemischen Veränderungen in kanadischen Laubholzarten beim Reibschweißen}

\section{Zusammenfassung}

Untersucht wurden die thermochemischen Veränderungen, die beim Einbringen von Dübeln mittels Reibschweißen in zwei in Kanada für Innenanwendungen häufig verwendeten Laubholzarten Zuckerahorn (Acer saccharum) und Gelbbirke (Betula alleghaniensis) auftreten. Die Schweißfläche zwischen den zwei verbundenen Holzteilen, einem Dübel und einem Holz, und dem nicht betroffenen Holz wurden verglichen, um unterschiedliche mechanische Eigenschaften beider Holzarten anhand von PyrolyseGaschromatographie - Massenspektrometrie (Py-GC/MS), Fourier-TransformationsInfrarot-Spektroskopie in abgeschwächter Totalreflexion (ATR-FTIR) und RöntgenPhotoelektronenspektroskopie zu bestimmen. Die beim Reibschweißen emittierten Gase wurden bestimmt mittels Py-GC/MS und Gaschromatographie gekoppelt mit einem Wärmeleitfähigkeitsmesser und einem Flammenionisationsdetektor (GC-TCD/FID. Die Ergebnisse zeigten, dass beim Reibschweißen von Birken- und Ahornholz Hemicellulosen abgebaut werden und auch das Ligninpolymer depolimerisiert wird. Die Güte der Verschweißung hängt deswegen direkt von den Eigenschaften der zu verschweißenden Holzbestandteile ab, insbesondere dem Lignin und der Kohlenhydrate. Veränderungen des Lignins an der Schweißfläche waren bei Zuckerahorn größer als bei Gelbbirke und bestätigen damit die unterschiedlichen mechanischen Eigenschaften beider Holzarten. Die Gasanteile waren bei beiden Holzarten vergleichbar und im Rauch, der beim Schweißen entsteht, wurden keine schädlichen Gase festgestellt.

\section{Introduction}

Rotational wood-dowel welding by mechanical friction has been shown to rapidly yield wood joints of considerable strength (Pizzi et al. 2004; Belleville et al. 2012). The technique consists of assembling solid wood pieces by fusing the wood constituents at the contact surfaces without interposing an adhesive. This ecological alternative for panelling and assembling wood components offers the potential to increase productivity while reducing costs in the hardwood furniture industry. Commonly used adhesives such as polyvinyl acetate (PVA) require long curing time (up to 24 hours). Moreover, they are generally derived from non-renewable fossil resources, making the end product expensive from both an ecological and economic standpoint. They also pose a recovery problem, as they are considered a source of contamination in biomass energy methods and wooden waste recycling (Gilbert 2005; Vallée and Buelna 2006). 
Since wood welding shortens the production cycle and reduces dependence on the petrochemical industry, it has received increasing attention. By replacing synthetic resins with the intrinsic lignin binders present in lignocellulosic fibre materials, the depletion of fossil resources could be abated. Wood, which is a renewable, $\mathrm{CO}_{2}$ neutral raw material, can play a key role in sustainable development and have a significant impact on responsible residual waste management. However, only a few studies on wood welding in North American species are available, and they have not fully addressed the chemical changes that occur during wood welding. A deeper knowledge of this process would enable further improvements in welding techniques and the mechanical properties of the welded joint.

Different thermochemical processes have been examined to deepen the understanding of the wood welding process. Some authors have investigated cross-link formation within lignin following extended heating (e.g., Sanderman and Augustin 1964). Native lignin (in wood) or only slightly modified lignin under dry conditions has been demonstrated to soften at $205{ }^{\circ} \mathrm{C}$ (Salmén 1982). Sudo et al. (1985) observed cross-linking reactions while heating beech (Fagus crenata) wood chips with pressurized steam. Lignin has also been processed into a plastic material to improve mechanical properties of binderless board (Anglès et al. 1999, 2001; Velásquez et al. 2002, 2003; van Dam et al. 2004). Cellulose fibrils can bond together after steam explosion (Tanahashi et al. 1989). Windeisen and Wegener (2008) observed characteristic changes in aromatic skeletal vibrations in European beech (Fagus sylvatica), indicating condensation reactions of lignin during different thermal treatments (combustion and thermal treatment). Chemical investigations related to wood welding have also been conducted by Gfeller et al. (2003) and Stamm et al. (2006).

Differences in wood polymer composition appear to influence wood performance during the welding process, and consequently the mechanical properties of the welded material. In a previous study, Sun et al. (2010) investigated chemical changes occurring at the welding interface of sugar maple (Acer saccharum) and yellow birch (Betula alleghaniensis) using a manually operated bench drill. The authors suggested that the mechanical performance differences between the two species might be related to lignin structure and welding temperature. The more pronounced guaiacyl character of maple lignin versus birch could explain the preferential condensation reactions of the guaiacyl moieties in maple lignin, implicating formaldehyde and furanic compounds released from lignin and carbohydrates during the process. However, recent measurements of peak welding temperatures in the same species using a fully automated machine specifically designed for wood-dowel welding (Belleville et al. 2012) were lower than those observed by Sun et al. (2010).

Temperature differences between these two studies could have resulted in different temperature loads on the wood and chemical changes at the welding interface, as significant lignin degradation reactions occurred at temperatures higher than $280^{\circ} \mathrm{C}$ (Kudo and Yoshida 1957; Hill 2006). The aims of the present study were to 1 ) investigate chemical changes occurring at the welding interface produced by automated machine of sugar maple (Acer saccharum) and yellow birch (Betula alleghaniensis); and 2) determine the gases released during welding under conditions of optimised welding parameters (Belleville et al. 2012). 


\section{Material and methods}

\subsection{Sample preparation}

All wood samples were preconditioned in a conditioning room at $20{ }^{\circ} \mathrm{C}$ and $60 \%$ relative humidity (RH) until constant mass was reached. Commercially manufactured plain-shank dowels of sugar maple (Acer saccharum) and yellow birch (Betula alleghaniensis) wood, $9.68 \mathrm{~mm}$ in diameter and $82 \mathrm{~mm}$ in length, were inserted using a rotational wood-dowel welding machine into pre-drilled holes $25 \mathrm{~mm}$ in depth and $7.67 \mathrm{~mm}$ in diameter in selected and prepared wood slats of $30 \times 30 \times 225 \mathrm{~mm}^{3}$. Species were not mixed between slats or dowels. Two welding parameter sets were used based on results from a previous study (Belleville et al. 2012): a rotational speed of $1000 \mathrm{rpm}$ and a $25 \mathrm{~mm} \mathrm{~s}^{-1}$ speed of insertion for sugar maple; $1000 \mathrm{rpm}$ and $16 \mathrm{~mm} \mathrm{~s}^{-1}$ for yellow birch. Following welding, the material was again stored at $20{ }^{\circ} \mathrm{C}$ and $60 \% \mathrm{RH}$ for 7 days prior to testing. Each specimen consisted of one dowel inserted into a wood slat substrate. According to standard tensile strength test method ASTM D1037 (ASTM 2006) and using a universal testing machine (MTS QT $5 \mathrm{kN}$ ), the dowel excess was pulled off the wood substrate. Reference wood (Ref) and welded material $(W M)$ refer to the unwelded wood and the wood at the welded interface, respectively (Fig. 1a). Chemical analyses were performed on both species. Samples for pyrolysis (Py-GC/MS) analysis were collected by scraping wood from Ref and WM samples. Wood-welded dowels were cut transversally to prepare samples for X-ray photoelectron spectroscopy (XPS) and attenuated total reflection Fourier transform infrared spectroscopy (ATRFTIR) (Fig. 1b).

\subsection{Thermochemical changes at the welded interface}

\subsubsection{Pyrolysis gas chromatography - mass spectrometry (Py-GC/MS)}

Samples were pyrolysed at $550{ }^{\circ} \mathrm{C}$ in a helium atmosphere using a Pyroprobe 2000 pyrolyzer (CDS Analytical, PA, USA) coupled to a gas chromatograph (GC) (Varian CP 3800) and a mass spectrometer (MS) (Varian Saturn 2200 MS/MS, 30-650 a.m.u.). The flow rate of the carrier gas was $1.0 \mathrm{ml} \mathrm{min}^{-1}$. The pyrolysis interface and the $\mathrm{GC}$ injector were set at $250{ }^{\circ} \mathrm{C}$. Pyrolysis products were separated in a Varian FactorFour capillary column (VF-5 ms, $30 \mathrm{~m} \times 0.25 \mathrm{~mm} \times$ $0.25 \mu \mathrm{m}$ ). Pyrolysis was performed from $250{ }^{\circ} \mathrm{C}$ (holding for $10 \mathrm{~s}$ ) to pyrolysis temperature (holding for $30 \mathrm{~s}$ ) with a heating rate of $6{ }^{\circ} \mathrm{C} \mathrm{ms}^{-1}$. The $\mathrm{GC}$ oven was kept at $45^{\circ} \mathrm{C}$ for $4 \mathrm{~min}$ and then heated to $280{ }^{\circ} \mathrm{C}$ at $4{ }^{\circ} \mathrm{C} \mathrm{min}{ }^{-1}$. The final temperature was held for $15 \mathrm{~min}$. The MS was operated in electron impact (EI) mode using $70 \mathrm{eV}$ energy and the mass range $\mathrm{m} / \mathrm{z}$ 35-450 was scanned in $36 \mathrm{~s}$. Compounds were identified by comparing the obtained mass spectra with those from the National Institute Standards and Technology (NIST 2000) mass spectral libraries and those reported in the literature (Faix et al. 1990, 1991; del Río et al. 2005; Nonier et al. 2006; Omrani et al. 2008; Sun et al. 2010). Relative compound distributions were calculated for each carbohydrate and lignin-derived pyrolysis product from the relevant peak areas. The summed areas of the relevant peaks were normalized to $100 \%$ (all products) and separate summations were performed for lignin-derived compounds containing oxygenated functions (Oxy) in side chains (aldehydes, ketones, alcohols, and esters) and for lignin-derived compounds with alkyl (Alk) side chains only. Oxy/Alk ratios for both guaiacyl $(G)$ and syringyl $(S)$ compounds were thus 
calculated for Ref and WM samples. Data from three pyrolysis experiments of 1-2 mg were used to determine average values.

\subsubsection{Attenuated total reflection Fourier transform infrared spectroscopy (ATR-FTIR)}

ATR-FTIR measurements were performed using a Spectrum 400 spectrometer (Perkin Elmer, UK) in the wavenumber range $4000-600 \mathrm{~cm}^{-1}$. Samples were pressed against a high refractive index crystal (Diamond/ZnSe) to allow the incident radiation to penetrate the sample surface through the crystal. ATR-FTIR sampling depth was in the $0.3-3 \mu \mathrm{m}$ range. All spectra were measured at $4 \mathrm{~cm}^{-1}$ resolution and the average of 64 scans was recorded. Water absorption peaks were automatically eliminated by the Atmospheric Vapor Compensation function, an algorithm performed in real time without the need to generate reference spectra of atmospheric absorptions. Spectra were baseline corrected using Origin Pro 8.5.1 software at 785, 1816, and $3700 \mathrm{~cm}^{-1}$, following Nuopponen et al. (2004). A $1036 \mathrm{~cm}^{-1}$ band assigned to CO stretching was used to normalize the obtained spectra (Delmotte et al. 2008).

\subsubsection{X-ray photoelectron spectroscopy (XPS)}

XPS analyses were performed to identify the elements present at the sample surfaces using a Kratos Axis-Ultra spectrometer (Kratos Analytical, UK). Elemental composition was measured on 3 ref and $3 W M$ samples for each species. Survey spectra were recorded to provide quantitative data to determine the apparent composition. High-resolution C1s spectra were recorded to investigate the chemistry of the most abundant elements. Four samples were mounted simultaneously onto the sample holder bar and received no treatment other than normal vacuum pumpdown. The take-off angle of the emitted photoelectrons was adjusted to $30^{\circ}$ to the surface normal. The base pressure in the analysis chamber during XPS analysis was below $5 \times 10^{-10}$ Torr. Hybrid lens mode was used to ensure maximum sensitivity, with an analysed spot equivalent in size to the monochromatic X-ray beam (dimensions $800 \times 400 \mu \mathrm{m}$ ). The analyser was run in constant pass energy mode. XPS spectra were recorded using a monochromatic Al source operating at $300 \mathrm{~W}$. High-resolution spectra used for chemical analysis were recorded at a nominal energy resolution of $0.5 \mathrm{eV}(10 \mathrm{eV}$ pass energy and $0.025 \mathrm{eV}$ steps $)$. The survey spectra used for quantitative elemental analysis were recorded in $1 \mathrm{eV}$ steps and at $160 \mathrm{eV}$ pass energy. The binding energy scale was corrected by referring to the polyaromatic peak in the $\mathrm{C} 1 \mathrm{~s}$ spectrum as $284.6 \mathrm{eV}$. Shirley backgrounds were subtracted from the spectra. A mixed GaussianLorentzian product function was applied to curve fit the C1s spectra (Sun et al. 2010). The

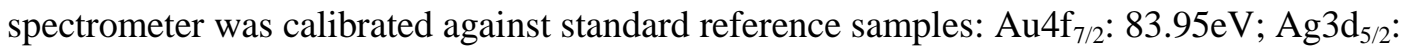
368.2eV; $\mathrm{Cu} 2 \mathrm{p}_{3 / 2}: 932.6 \mathrm{eV}$ (Seah et al. 1998).

\subsection{Characterisation of gas emissions}

\subsubsection{Analyses of volatile organic compounds}

Py-GC/MS was used to predict VOCs evolving from welding process. Wood material scraped from Ref samples for each studied species was pyrolysed according to specific wood-dowel welding temperature profiles determined in a previous study (Belleville et al. 2012). Samples were pyrolysed at $244{ }^{\circ} \mathrm{C}$ for sugar maple and $282{ }^{\circ} \mathrm{C}$ for yellow birch in a helium atmosphere to 
simulate the welding conditions determined in a previous study by the authors using the abovedescribed apparatus. The flow rate of the carrier gas was $1.0 \mathrm{ml} \mathrm{min}^{-1}$. The pyrolysis was performed from ambient temperature to the wood-dowel welding interface peak temperature (holding for $30 \mathrm{~s}$ ), with a heating rate of $130{ }^{\circ} \mathrm{C} \mathrm{s}^{-1}$ for birch and $139{ }^{\circ} \mathrm{C} \mathrm{s}^{-1}$ for maple. The GC oven was kept at $45{ }^{\circ} \mathrm{C}$ for $4 \mathrm{~min}$ and then heated at $4{ }^{\circ} \mathrm{C} \mathrm{min}^{-1}$ to peak temperature. The final temperature was held for $15 \mathrm{~min}$. The MS was operated in EI mode using $70 \mathrm{eV}$ energy, and the mass range $\mathrm{m} / \mathrm{z} 35-450$ was scanned in $36 \mathrm{~s}$. Compounds were identified by comparing the obtained mass spectra with the literature, as mentioned in section 2.2.1. Three injections of 1-2 mg were conducted per species.

\subsubsection{Analysis of non-condensable gases and light hydrocarbons}

Non-condensable gases and light hydrocarbons produced during wood-dowel welding for both species were analysed with a Clarus 480 GC coupled with TCD and FID (PerkinElmer, UK). A universal air sample pump (SKC 224-PCXR4, PA, USA) at a constant flow rate of 2.5 LPM (Anonymous 2010) was used to trap the VOCs released during the wood welding. The noncondensable gases $\left(\mathrm{N}_{2}, \mathrm{H}_{2}, \mathrm{CO}, \mathrm{CO}_{2}, \mathrm{CH}_{4}\right.$, and $\left.\mathrm{C}_{2} \mathrm{H}_{4}\right)$ were collected in $5 \mathrm{~L}$ sampling bags (FlexFoil@) flushed three times with nitrogen prior to sampling. The VOCs from 15 wood-dowel welding samples for each species were trapped and injected into the GC-TCD/FID using a $1 \mathrm{~mL}$ injection loop and 2 coupled columns (HayeSep N and Molecular Sieve 13X). Oven temperature was $60{ }^{\circ} \mathrm{C}$ and pressure was $150 \mathrm{KPa}$. Three injections were conducted per species.

\section{Results and discussion}

\subsection{Thermochemical changes at the welded interface}

Chemical analysis was performed to determine the thermochemical changes in sugar maple and yellow birch following wood welding.

\subsubsection{Py-GC/MS}

A higher syringyl/guaiacyl ratio (S/G) for birch than for maple was determined for both Ref and $W M$ (Tab. 1), as reported previously for manual wood welding with the same species (Sun et al. 2010). The difference of peak temperatures at the interface determined during welding of maple $\left(244^{\circ} \mathrm{C}\right)$ and birch $\left(282^{\circ} \mathrm{C}\right)$ (Belleville et al. 2012) could be related to the results of Sarni et al. (1990) who found that $\mathrm{S} / \mathrm{G}$ in oak lignin increased with increasing thermal treatment temperature. Furthermore, G-S lignins with higher $\mathrm{G}$ unit content generally have more condensed structures due to the availability of the aromatic C5 position for coupling during lignin biosynthesis. The higher proportion of guaiacyl structures in the native lignin of sugar maple wood than in yellow birch wood could explain the higher susceptibility of sugar maple to condensation reaction during wood welding.

The lignin-related pyrolysis products from maple and birch Ref and WM are presented in Table 2 . More lignin-related pyrolysis products showed significant changes following welding for sugar maple (9) than for yellow birch (6). This observation corroborates the welded mechanical property differences between the two species. More changes at the welded interface suggest that sugar maple has a stronger bond line. A significant increase in G-aldehydes (from 3.0 to 3.7\%) 
identified by Py-GC/MS following welding was observed for maple, essentially because the vanillin proportion increased significantly. No significant variation in G-ketones was observed, although a small but significant increase in guaiacyl acetone was noted. A significant increase in S-aldehydes (from 10.4 to $14.6 \%$ ) following welding was observed due to a significant increase in syringaldehyde (from 6.8 to $9.9 \%$ ). No significant difference in S-ketones was observed, although a small but significant increase in syringyl acetone (from 1.2 to $1.5 \%$ ) was noted. A significant increase (from 0.3 to 0.4 ) in Oxy/Alk (lignin-derived compounds containing oxygenated functions (Oxy) in side chains and alkyl (Alk) side chains only) was observed due to a $40 \%$ increase in S-aldehyde and a significant decrease in 4-methyl-syringol (from 7.7 to $3.9 \%$ ). $\mathrm{S}$ units depolymerised more rapidly than the more condensed $\mathrm{G}$ units, which could explain the increased Oxy/Alk for S derivatives versus $\mathrm{G}$ derivatives. The significant increase in guaiacol and syringol produced by analytical pyrolysis of $W M$ versus Ref for maple (Table 2) could also be explained by lignin depolymerisation through ether bonds cleavage reactions which took place during welding releasing these phenols. The fact that this increase is more important for maple than birch probably indicated the higher extent of changes in maple lignin taking place during welding of maple wood versus birch wood.

As noted above, fewer significant changes were observed for yellow birch. No significant variation in S-ketone was noted, although propiosyringone decreased significantly (from 2.1 to $1.4 \%$ ). A significant increase (from 1.3 to $2.5 \%$ ) in S-alcohols was observed, essentially related to a significant increase in trans-sinapyalcohol (from 0.7 to $1.8 \%$ ). However, Oxy/Alk remained essentially unchanged between Ref and WM for yellow birch.

Two degradation mechanisms may be proposed during wood welding: (1) cleavage of the side chains in phenylpropane units in maple lignin resulting in an increase in the phenyl units with shortened side chains $\left(\mathrm{C}_{6}-\mathrm{C}_{1}+\mathrm{C}_{6}-\mathrm{C}_{2} / \mathrm{C}_{6}-\mathrm{C}_{3}\right)$ for both guaiacol and syringol; (2) general oxidation (aldehyde and ketone formation) which was more pronounced in $\mathrm{S}$ units for maple. These mechanisms could be related to preferential side-chain oxidation at $\mathrm{C} \alpha$ (vanillin and syringaldehyde formation) (Fig. 2a). A decrease in $\mathrm{C}_{6}-\mathrm{C}_{3}$ products determined by analytical pyrolysis of $W M$ could be related to a cleavage at $C \beta-C \gamma$, resulting in formaldehyde loss and the formation of a resistant vinyl ether bond (4-vinyl ether-G and 4-vinyl ether-S, mechanism presented in Fig. 2d).

A significant increase in guaiacyl unit lignin $\left(\mathrm{G}-\mathrm{C}_{6} \mathrm{C}_{1}+\mathrm{C}_{6} \mathrm{C}_{2} / \mathrm{C}_{6} \mathrm{C}_{3}\right.$, Table 2) following welding for sugar maple supports the above-mentioned reports of formaldehyde formation from lignin units (Fig 2d). The increase in Oxy/Alk, G-aldehyde and S-aldehyde for sugar maple related to $\beta-\mathrm{O}-4$ cleavage also supports a depolymerisation route for lignin such as proposed in Figure $2 \mathrm{c}$ (route 1). The newly acquired mobility of these components then allows cellulose fibrils to bond (Tanahashi et al. 1989).

The increased proportion of amorphous carbohydrates following welding was observed previously by Gfeller et al. (2003). The produced furfural self-polymerised or reacted with lignin aromatic nuclei, whereas hemicelluloses deacetylation yielded the free acetic acid, which catalysed the formation of furanic compounds from hemicelluloses. A significant increase in 5hydroxy-2-furfuraldehyde was observed in the pyrolysis products from WM compared to Ref for 
maple, whereas furfural content increased but not significantly for both maple and birch (carbohydrate-related pyrolysis products not presented here). A general increase in the furfural derived compounds was also observed in a previous study (Sun et al. 2010). The welded area yielded greater amounts of hemicelluloses-derived products such as furfural and furfuryl alcohol. Much of the acetic acid released from wood during pyrolysis can be attributed to hemicelluloses deacetylation (Tanahashi et al. 1989; Mohan et al. 2006). Consequently, partly degraded wood components become mobile, which loosens the inner stress in the crystalline region of cellulose. The only carbohydrate-related pyrolysis product that decreased significantly in $W M$ compared to Ref for both species was 3-hydroxy-2-methyl-2-cyclopenten-1-one. Hemicelluloses depolymerisation results in the formation of oligosaccharides and monosaccharides, the dehydration of the latter yielding furfural and hydroxymethylfurfural from pentosans and hexosans, respectively. Stamm et al. (2006) investigated chemical reactions and degradation processes in Norway spruce (Picea abies) during friction welding and found an increase in phenolic $\mathrm{OH}$ groups in the welded area. This has been related to the splitting of lignin macromolecules and the formation of smaller constituents with free phenolic $\mathrm{OH}$ groups, which are potential sites for cross-linking reactions with polysaccharide-derived furfural and hydroxymethyl furfural and other compounds. Furfural generated from hemicelluloses was also proposed as a possible contributor to self-bonding during hot pressing of binderless board (Mobarak et al. 1982; Suzuki et al. 1998). Most hemicelluloses do not yield significant amounts of levoglucosan during decomposition at $200-260{ }^{\circ} \mathrm{C}$ (Mohan et al. 2006). Cellulose degradation occurs at $240-350{ }^{\circ} \mathrm{C}$ to produce anhydrocellulose and levoglucosan, which means that the maximal welding temperatures determined in this study were insufficiently high to generate a significant amount of levoglucosan.

\subsubsection{ATR-FTIR}

ATR-FTIR was used to analyse wood component structures, more specifically, the chemical functional groups. The overall FTIR spectra of both Ref and WM samples revealed a number of changes after welding. Comparison of spectra showed significant structural changes between Ref and $W M$ for both species. The spectra show an increase in absorption in the functional region, particularly from $3700-3000 \mathrm{~cm}^{-1}$ (not presented), which corresponds to the $\mathrm{OH}$ group and suggests cleavage of the lignin ether bonds (route 1, Fig. 2c) and liberation of free phenolic hydroxyls. This is also confirmed by the increase in the band at $1740 \mathrm{~cm}^{-1}$, assigned to the nonconjugated carbonyl group following breakage at $\beta-\mathrm{O}-4$, as well as the higher peak at $1335 \mathrm{~cm}^{-1}$ originating from the phenolic hydroxyl groups, which suggests release of the phenolic hydroxyl groups from lignin splitting (Fig. 2b and 2c). The increase at $1110 \mathrm{~cm}^{-1}(\mathrm{OH}$ associated with cellulose) can be explained by the relative increase in cellulose content in the welded area due to hemicelluloses degradation. This finding is confirmed by the increases at $1235 \mathrm{~cm}^{-1}$ and $900 \mathrm{~cm}^{-1}$ associated with the production of acidic substances in the welded area as the result of acetyl group splitting from hemicelluloses.

According to Delmotte et al. (2008), the $1424 \mathrm{~cm}^{-1}$ and $1466 \mathrm{~cm}^{-1}$ bands, attributed to $\mathrm{CH}_{2}$ bending of crystalline and amorphous cellulose and to aliphatic $\mathrm{CH}$ bending of lignin (Colom et al. 2003; Hakkou et al. 2005), remain unaltered during welding. A peak shift for $W M$ versus Ref from 1158 to $1160 \mathrm{~cm}^{-1}$ and 1160 to $1162 \mathrm{~cm}^{-1}$ was observed for sugar maple and yellow birch, 
respectively. This suggests that the material in the welded area had greater crystalline cellulose content following the degradation of amorphous polysaccharides from cellulose and hemicelluloses due to rotational friction during welding. Delmotte et al. (2008) reported an apparent increase in cellulose crystallinity and hemicelluloses degradation following linear welding of European beech.

However, the changes that occurred during welding were more pronounced for maple than for birch. For example, a more pronounced peak was observed at $1650 \mathrm{~cm}^{-1}$, associated with a conjugated double bond for maple compared to birch. It appears that the more pronounced chemical changes during welding resulted in a stronger, more resistant welded bond line. The increases in absorptions at 1595, 1510, 1650, and $1425 \mathrm{~cm}^{-1}$ observed in spectra for $W M$ can be attributed to the increase in relative lignin content in the welded samples, which was more pronounced for maple. The absorptions at these wave numbers were attributed to lignins in other published results (Yang et al. 2007; Delmotte et al. 2008). Comparing Ref and WM spectra, the absorption at $1370 \mathrm{~cm}^{-1}$ increased for maple but not for birch. This absorption can be associated with lignin carbohydrate complexes (LCC), as discussed in previous studies (Kotilainen et al. 2000) and is in agreement with previous results by the authors (Sun et al. 2010).

The FTIR spectra results suggest that the more pronounced changes especially related to lignin observed for maple can explain the better mechanical performance of the welded joint for maple over yellow birch (Rodriguez et al. 2010; Belleville et al. 2012). Peaks between 1159 and 1742 $\mathrm{cm}^{-1}$ were also observed in the spectra. The increasing peak at $1335 \mathrm{~cm}^{-1}$ could be attributed to phenolic hydroxyl groups, due to ether bond splitting mechanisms proposed in Fig. 2a and 2c. A peak at $1450 \mathrm{~cm}^{-1}$ was also observed which supports that lignin was altered as a result of condensation and/or formation of $\mathrm{CH}_{2}$ bridges between lignin fragments ( $\mathrm{Lig}-\mathrm{CH}_{2}-\mathrm{Lig}$ ). A lower absorption peak at $1649 \mathrm{~cm}^{-1}$ was attributed to conjugated double bonds following lignin depolymerisation. Several structures issued from lignin splitting mechanisms proposed in Figure 2 contain conjugated double bonds $(2 \mathrm{a}, 2 \mathrm{~b}, 2 \mathrm{c})$.

\subsubsection{XPS}

The XPS results revealed surface changes in yellow birch and sugar maple in the wood dowel welding area. Several XPS survey spectra presented a particularity associated with an O1s peak meaning that the analysed volume was not homogenous in depth and that oxygen was depleted at the surface. The more pronounced the concavity at the surface, the greater the oxygen depletion (Tougaard 1989; Sreemany and Ghosh 1994). Elemental analysis was performed using survey scans, and results on $\mathrm{O} / \mathrm{C}$ are presented in Table 3.

A decrease in $\mathrm{O} / \mathrm{C}$ for birch and an increase for maple was determined for Ref. The O/C increase following welding for sugar maple indicates that chemical substances with oxygenated functionality were formed, such as proposed in Figure 2 b) and c) route 1 . This may have been caused by 1) the increase in free phenolic groups, and 2) the decrease in the typical (ether) bonds between the phenylpropane units in lignin, which is consistent with the Py-GC/MS results of this study. On the other hand, the decrease in $\mathrm{O} / \mathrm{C}$ in $W M$ for birch indicated a loss of oxygenated compounds. This could have been caused by the production of carbon-enriched material resulting either from the dehydration of initially present wood polymers or the formation of new 
components, as reported by Inari et al. (2006). In wood-to-wood welding, the adhesion mechanism requires high applied pressure to keep the pieces together. This reduces the available oxygen at the interface, and appears to have resulted in fast pyrolysis rather than slow or conventional pyrolysis. After slow pyrolysis, O/C would tend to decrease due to more significant cross-bonding via methylenic bridges, resulting in carbon-enriched material. During fast pyrolysis, the pyrolysis liquids, which are rich in oxygenated compounds, are formed by rapidly and simultaneously depolymerising and fragmenting cellulose, hemicelluloses, and lignin during the rapid increase in temperature (Mohan et al. 2006). This also favours the miscibility of these polymers, as discussed above. When the welding process is stopped, rapid quenching "freezes" the intermediate products of the fast pyrolysis degradation of hemicelluloses, cellulose, and lignin.

The quantitative analysis for Ref and $W M$ using the results of peak deconvolution of the C1s component is presented in Table 3. Based on deconvolution, the types of carbon bonds present in Ref and WM were determined and surface changes identified. Carbon bonds were deconvoluted into four components according to the number of C-bonded oxygen atoms: $\mathrm{C} 1$ class, or carbon atoms bonded with carbon or hydrogen atoms only, usually indicating a binding energy (BE) of $284.6 \mathrm{eV}$ ( $\mathrm{C}-\mathrm{C} / \mathrm{C}-\mathrm{H}$ bonds); $\mathrm{C} 2$ class, or carbon atoms bonded with one oxygen atom, and appearing at a higher $\mathrm{BE}$ compared to $\mathrm{C} 1(\mathrm{C}-\mathrm{O}$ bonds; $286.5 \mathrm{eV})$; $\mathrm{C} 3$ class, or carbon atoms bonded to a carbonyl or two non-carbonyl oxygen atoms $(\mathrm{C}=\mathrm{O}$ and $\mathrm{O}-\mathrm{C}-\mathrm{O} ; 287.9 \mathrm{eV})$; and $\mathrm{C} 4$ class, or carbon atoms bonded to a carbonyl and a non-carbonyl oxygen atom $(\mathrm{O}-\mathrm{C}=\mathrm{O}$ bonds; $289.2 \mathrm{eV})$.

The $\mathrm{C} 1$ contribution decreased in $W M$ for both sugar maple and yellow birch as compared to Ref. This could be mainly attributed to the general reactions of fragmentation of side chains (release of formaldehyde) and/or their oxidation in the welded interface (products presented in Fig. 2). The C2 contribution on the other hand increased in WM versus Ref for both yellow birch and sugar maple and more importantly so in sugar maple (Table 3 ). This change could be explained by the modification of wood components: 1) the degradation of amorphous polysaccharides which consist of their hydrolysis releasing hydroxyl groups and the increase in lignin with liberated phenolic hydroxyl groups following the splitting of ether bonds as previously reported (Sun et al. 2010); and 2) the loss of formaldehyde from the lignin and the formation of a new vinyl ether structure as proposed in Fig. 2d, also reported by Sun et al. (2010). The increase in C3 in WM versus Ref is pronounced for maple, probably reflecting the formation of carbonyl structures proposed by mechanisms presented in Fig. 2, while such increase is not recorded at all for birch, which could be taken as an evidence of lesser changes in birch lignin during welding as compared to maple which is related to better mechanical performance of welded maple compared to birch. The reactions discussed during welding are proposed to be catalysed by the acetic acid release during welding (splitting of acetyl groups from xylan). This could be confirmed by a small decrease in the $\mathrm{C} 4$ contribution from $W M$ versus Ref for both maple and birch (Table 3 ). The production of organic acid compounds was also confirmed by the ATR-FTIR spectra, which showed a peak at 892 and 1230/40 $\mathrm{cm}^{-1}$ attributed to organic acids (Colom et al. 2003; AIST 2011), and the Py-GC/MS results, which showed an increasing trend for acetic acid release following welding. The release of acetic acid will be definitely confirmed by the results of this study on VOCs determination. Due to its high crystallinity, cellulose begins to depolymerise only 
at $225^{\circ} \mathrm{C}$ (Fengel and Wegener 2003). High protonation of the reaction site and the presence of acids such as acetic acid produced by the high-temperature hydrolysis of the acetyl groups from xylan could potentially explain this reaction. The increase in the $\mathrm{C} 2$ component for sugar maple could be associated with the formation of furanic compounds from xylan as well as the release of phenolic/carbonyl compounds from lignin depolymerisation (Fig. 2c).

The increase in C3 for sugar maple suggests that oxidised products were formed during welding. Several carbonyl containing structures are proposed by the mechanisms presented in Fig. 2a and 2c. Oxidation products such as quinones are also formed when wood is heat treated, which is associated with the colour change during heat treatment. In the first step of pyrolysis, hydroxyl functions are thermo-oxidized into corresponding aldehydes, which could explain the increase in $\mathrm{C} 3$ components. With respect to the $\mathrm{C} 4$ component $(\mathrm{O}-\mathrm{C}=\mathrm{O})$, this study showed that the welded materials contained less carboxyl and/or acetyl groups than the reference material, which points to a thermodegradation of hemicelluloses resulting in the loss of acetyl groups.

\subsection{Gases analysis}

\subsubsection{VOCs analysis}

The VOCs released from controlled pyrolysis processes performed following temperature profiles determined for wood-dowel welding of maple and birch woods were determined by Py-GC/MS and results are presented in Tables 4 and 5. The main compounds released from sugar maple wood at maximum welding temperature $\left(244^{\circ} \mathrm{C}\right)$ were 4-ethenyl-2-methoxyphenol, trans-2methoxy-4-[(E)-prop-1-enyl]phenol, and 2,6-dimethoxy-4-prop-1-enylphenol. For yellow birch $\left(282{ }^{\circ} \mathrm{C}\right)$, the most notable compounds identified were 3,4-dihydro-2,5-dimethyl-2H-pyran-2methanol, trans-2-methoxy-4-[(E)-prop-1-enyl]phenol, and trans-2,6-dimethoxy-4-prop-1enylphenol.

The compounds identified among the products of sugar maple pyrolysis with lowest retention times (0-15 $\mathrm{min})$ are essentially polysaccharide related degradation products followed by the products associated with thermal degradation of lignin. The lignin-related products released as VOCs during the pyrolysis simulating wood welding of sugar maple (at maximal welding temperature of $244^{\circ} \mathrm{C}$ ) were 4-vinylguaiacol, isoeugenol, and trans-4-propenyl syringol (retention times 24.82, 29.31, $36.59 \mathrm{~min}$ ). The most abundant VOCs released from wood-welding of yellow birch at $282{ }^{\circ} \mathrm{C}$ were also associated with lignin degradation products $(29.17,36.50$ min). Isoeugenol and 4-propenylsyringol were identified to be the most abundant VOCs released during welding for both species, which is consistent with data reported previously for European beech (Omrani et al. 2008).

The presence of acetic acid confirmed the degradation of hardwood xylan containing acetyl groups. Furfural production through pentosan transformation under acidic conditions was determined in the experiments (Tables 4 and 5), thus confirming the discussed reactions at the weldline. The presence of furanic compounds for yellow birch (retention times of 7.30, 10.50, $11.88 \mathrm{~min}$, Table 4) and sugar maple (retention times of 7.15, 11.86, $15.10 \mathrm{~min}$, Table 5) was also detected in a previous study on European beech (Fagus sylvatica) wood welding (Omrani et al. 
2008). For both species, most of the VOCs identified during pyrolysis are non-toxic products derived from degradation of wood polymers.

\subsubsection{Non-condensable gases and light hydrocarbons}

The non-condensable gases (NCG) and the light hydrocarbons emitted during wood-dowel welding of both studied species were also analysed using GC/TCD-FID following their collection in sampling bags during welding as described in material and methods section. The obtained results are presented in Table 6 . The NCG proportions are quite similar for the two species, with only minor differences. GC-TCD analyses showed that carbon dioxide $\left(\mathrm{CO}_{2}\right)$ accounted for $0.1 \%$ (standard deviation 0.0) of non-condensable gases released from both birch and maple wood during welding. $\mathrm{CO}_{2}$ is naturally present in the atmosphere at approximately $0.035 \%$. Short-term exposure to $\mathrm{CO}_{2}$ at below $2 \%$ concentration (20,000 parts per million or ppm) has not been reported to cause harmful effects (CCHST 2012). According to Health Canada (1989), the lowest $\mathrm{CO}_{2}$ concentration at which adverse health effects were observed in humans was $7000 \mathrm{ppm}$, at which increased blood acidity was observed after several weeks of continuous exposure. No carbon monoxide was produced during welding. These results are in accordance with those of Omrani et al. (2009), who analysed the emission gases emitted as smoke in linear vibration welding of European beech (Fagus sylvatica). Among the light hydrocarbons identified by GCFID analyses, methane was the most abundant, averaging 26.2 and 30.5 ppm for maple and birch, respectively. It is known that methane is not toxic below the lower exposure limit of 5\%, or 50000 ppm (CCHST 2012). Traces of ethane, ethylene, and acetylene were also measured. Higher welding temperature and differences in sampling and analytical methods (ground powder in a sealed furnace at $200{ }^{\circ} \mathrm{C}$ ) may account for some of the variations between the results of this study and those reported by Omrani et al. (2009). The overall results presented here appear to confirm that wood-dowel welding is an ecological technology which is not hazardous for furniture industry workers or consumers.

\section{Conclusion}

The results of this investigation showed that thermal treatment of birch and maple wood degrades hemicelluloses through acid hydrolysis and dehydration mechanism and affects lignin polymer through depolymerisation reactions. Although lignin appears to be a major contributor in wood welding, the welded site also showed increased amounts of polysaccharide-derived products.

The degradation of amorphous polysaccharides (including amorphous part of cellulose) due to rotational friction during welding explains why the material at the welding site contained more crystalline cellulose. Cleavage of the lignin ether bonds and the release of free phenolic hydroxyls were confirmed by FTIR.

The Py-GC/MS and XPS results associated with the O/C increase following welding for maple indicate that chemical substances containing oxygenated functionality were formed, which could be associated with either an increase in free phenolic groups and/or a decrease in typical (ether) bonds between phenylpropane units in lignin following welding. On the other hand, the decrease in $\mathrm{O} / \mathrm{C}$ at the welded site for birch wood indicates a loss of oxygenated compounds. The 
production of carbon-enriched material, resulting from either the dehydration of initially present wood polymers or the formation of new components, could explain these changes.

The gas emission results show similar proportions of non-condensable gases for the two studied species. Most of the volatile compounds identified during pyrolysis were non-toxic products derived from degradation of wood polymers. The composition of these NCG was close to that found in pure air. No carbon monoxide was produced during welding, and only traces of hydrogen and carbon dioxide were present. The knowledge gained on VOCs provides valuable information for air safety inspections. The proportion of detected VOCs was relatively low and below the lower exposure limits. Hence, wood welding appears to be an ecological technique for assembling furniture components and other applications, and is not harmful for human health.

The impact of wood species on chemical changes occurring at the welding interface during wooddowel welding has clearly been demonstrated. This technique can therefore be used for ecoconception of wood-welded panels for furniture and other indoor appearance applications.

\section{Acknowledgements}

The authors would like to thank Le Fonds Québécois de la Recherche sur la Nature et les Technologies (FQRNT) for a research grant (T. Stevanovic) and the Natural Sciences and Engineering Research Council of Canada (NSERC) and FPInnovations for a scholarship (B.

Belleville). Thanks are extended to the Centre de Recherche Industrielle du Québec for technical support. We also wish to express our thanks to Alain Adnot, Université Laval, for his contribution to the XPS analysis, to Florian Prost, SEREX, for his support in GC/TCD-FID analysis and to Yves Bédard, Université Laval, for his assistance with the laboratory work. 


\section{Literature Cited}

Advanced Industrial Science and Technology (AIST) (2011) Spectral database for organic compounds. http://riodb01.ibase.aist.go.jp/sdbs/cgi-bin/direct_frame_top.cgi. Accessed 19 December 2011

Anglès MN, Ferrando F, Farriol X, Salvadó J (1999) Binderless composites from pretreated residual softwood. J Appl Polym Sci 73:2485-2492

Anglès MN, Ferrando F, Farriol X, Salvadó J (2001) Suitability of steam exploded residual softwood for the production of binderless panels. Effect of the pre-treatment severity and lignin addition. Biomass Bioenerg 21:211-224

Anonymous (2010) Operating Instructions - Universal Sample Pump. Catalog No. 224-PCXR4. SKC. PA, USA

American Society for Testing and Materials (2006) Standard test methods for evaluating properties of wood-base fiber and particle panel materials. ASTM D1037. PA, USA

Belleville B, Stevanovic T, Pizzi A, Cloutier A, Blanchet P (2012) Determination of optimal wood welding parameters for two North American hardwood species. J Adhes Sci Technol (In Press).

Centre Canadien d'Hygiène et de Sécurité au Travail (CCHST) (2012) Effets du dioxyde de carbone sur la santé.

http://www.cchst.ca/oshanswers/chemicals/chem_profiles/carbon_dioxide/health_cd.html.

Accessed 16 January 2012

Colom X, Carrillo F, Nogués F, Garriga P (2003) Structural analysis of photodegraded wood by means of FTIR spectroscopy. Polym Degrad Stabil 80:543-549

Delmotte L, Ganne-Chedéville C, Leban J-M, Pizzi A, Pichelin F (2008) CP-MAS C ${ }^{13}$ NMR and FT-IR investigation of the degradation reactions of polymer constituents in wood welding. Polym Degrad Stab Stabil 93:406-412

del Río JC, Gutiérrez A, Hernando M, Landín P, Romero J, Martínez AT (2005) Determining the influence of eucalypt lignin composition in paper pulp yield using Py-GC/MS. J Anal Appl Pyrol $74: 110-115$

Faix O, Meier D, Fortmann J (1990) Thermal degradation products of wood: gas chromatographic separation and mass spectrometric characterization of monomeric lignin derived products. Holz Roh Werkst 48:281-285

Faix O, Fortmann J, Bremer J, Meier D (1991) Thermal degradation products of wood: gas chromatographic separation and mass spectrometric characterization of polysaccharide derived products. Holz Roh Werkst 49:213-219 
Fengel D, Wegener G (2003) Wood - Chemistry, Ultrastructure, Reactions. Verlag Kessel, Munich, Germany

Geib SM, Filley TR, Hatcher PG, Hoover K, Carlson JE, Jimenez-Gasco M, Nakagawa-Izumi A, Sleighter RL, Tien M (2008) Lignin degradation in wood-feeding insects. In the Proceedings of the National Academy of Sciences of the United States of America 105(35):12932-12937

Gfeller B, Zanetti M, Properzi M, Pizzi A, Pichelin F, Lehmann M, Delmotte L (2003) Wood bonding by vibrational welding. J Adhes Sci Technol 17(11):1573-1589

Gilbert, V (2005) Caractérisation des résidus provenant de l'industrie de la seconde transformation des panneaux de particules et de fibres. Dissertation, Université Laval

Hakkou M, Pétrissans M, Zoulalian A, Gérardin P (2005) Investigation of wood wettability changes during heat treatment on the basis of chemical analysis. Polym Degrad Stabil 89:1-5

Health Canada (1989) Exposure Guidelines for Residential Indoor Air Quality - A Report of the Federal-Provincial Advisory Committee on Environmental and Occupational Health. Ontario, Canada

Hill CAS (2006) Wood Modification: Chemical, thermal and other processes. Chapter 5. Wiley, Chichester, UK. pp 99-127

Inari GN, Pétrissans M, Lambert J, Ehrhardt JJ, Gérardin P (2006) XPS Characterization of wood chemical composition after heat treatment. Surf Interface Anal 38(10):1336-1342

Kotilainen RA, Toivanen TJ, Alén RJ (2000) FTIR monitoring of chemical changes in softwood during heating. J Wood Chem Technol 20(3):307-320

Kudo K, Yoshida E (1957) On the decomposition process of wood constituents in the course of carbonization, I. The decomposition of carbohydrate and lignin in mizunara (Quercus crispula Blume) wood. J Jap Wood Res Soc 3(4):125-127

Li J, Henriksson G, Gellerstedt G (2007) Lignin depolymerization/repolymerization and its critical role for delignification of aspen wood by steam explosion. Bioressource Technol 98(16):3061-3068

Mobarak F, Fahmy Y, Augustin H (1982) Binderless lignocellulose composite from bagasse and mechanism of self-bonding. Holzforschung 36:131-135

Mohan D, Pittman Jr CU, Steele PH (2006) Pyrolysis of wood/biomass for bio-oil: A critical review. Energ Fuel 20(3):848-889

National Institute Standards and Technology (2000) XPS Database. NIST Standard Reference Database 20, Version 3.3.

Nonier MF, Vivas N, Vivas de Gaulejac N, Absalon C, Soulié PH, Fouquet E (2006) Pyrolysisgas chromatography/mass spectrometry of Quercus sp. wood: Application to structural 
elucidation of macromolecules and aromatic profiles of different species. J Anal App Pyrol 75:181-193

Nuopponen M, Wikberg H, Vuorinen T, Maunu SL, Jamsa S, Viitaniemi P (2004) Heat-Treated Softwood Exposed to Weathering. J Appl Polym Sci 91:2128-2134

Omrani P, Pizzi A, Mansouri HR, Leban J-M, Delmotte L (2009) Physico-chemical Causes of the Extent of Water Resistance of Linearly Welded Wood Joints. J Adhes Sci Technol 23(6):827-837

Omrani P, Mason E, Pizzi A, Mansouri HR (2008) Emission of gases and degradation volatiles from polymeric wood constituents in friction welding of wood dowels. Polym Degrad Stabil 93(4):794-799

Pizzi A, Leban J-M, Kanazawa F, Properzi M, Pichelin F (2004) Wood dowel bonding by highspeed rotation welding. J Adhes Sci Technol 18:1263-1278

Rodriguez G, Diouf P, Blanchet P, Stevanovic T (2010) Wood dowel bonding by high-speed rotation welding - Application to two Canadian hardwood species. J Adhes Sci Technol 24(810):1423-1436

Salmén NL (1982) Temperature and water induced softening behavior of wood fiber based materials. Dissertation, Swedish Forest Products Research Laboratory, Paper Technology Department, Stockholm, Sweden

Sanderman W, Augustin H (1964) Chemical investigations on the thermal decomposition of wood - Part III: Chemical investigation on the course of decomposition. Holz Roh Werkst 22:377-386

Sarni F, Moutounet M, Puech JL, Rabier P (1990) Effect of heat-treatment of oak wood extractable compounds. Holzforschung 44(6):461-466

Schäfer M, Roffael E (2000) On the formaldehyde release from wood. Holz Roh Werkst 58:259264

Seah MP, Gilmore LS, Beamson G (1998) XPS: Binding energy calibration of electron spectrometers 5 - Re-evaluation of the reference energies. Surf Interface Anal 26(9):642-649

Sreemany M, Ghosh TB (1994) On the XPS peak shape analysis. Appl Surf Sci 81(3):365-375

Stamm B, Windeisen E, Natterer J, Wegener G (2006) Chemical investigations on the thermal behaviour of wood during friction welding. Wood Sci Technol 40:615-627

Sudo K, Shimizu K, Sakurai K (1985) Characterization of steamed wood lignin from beech wood. Holzforschung 39:281-288

Sun Y, Royer M, Diouf P, Stevanovic T (2010) Chemical changes induced by high-speed rotation welding of wood - Application to two Canadian hardwood species. J Adhes Sci Technol 24(810):1383-1400 
Suzuki S, Shintani H, Park SY, Saito K, Laemsak N, Okuma M, Iiyama K (1998) Preparation of binderless boards from steam exploded pulps of oil palm (Elaeis guineensis Jaxq.) fronds and structural characteristics of lignin and wall polysaccharides in steam exploded pulps to be discussed for self-bindings. Holzforschung 52:417-426

Tanahashi M, Goto T, Horii F, Hirai A, Higuchi T (1989) Characterization of steam-exploded wood, III, Transformation of cellulose crystals and changes of crystallinity. Mokuzai Gakkaishi 35:654-662

Tougaard S (1989) Practical algorithm for background subtraction. Surf Sci 216(3):343-360

Vallée V, Buelna G (2006) La valorisation des résidus de panneaux à base de bois Centre de recherche industrielle du Québec, Innovations technologiques - TE.

http://www.icriq.com/fr/productique_tfp.html/-/asset_publisher/n2sB/content/la-valorisation-desresidus-de-panneaux-a-base-de-bois/maximized._Accessed 11 February 2012

van Dam JEG, van den Oever MJA, Teunissen W, Keijsers ERP, Peralta AG (2004) Process for production of high density/high performance binderless boards from whole coconut husk. Part 1: lignin as intrinsic thermosetting binder resin. Ind Crop Prod 19:207-216

van der Hage E, Mulder M, Boon J (1993) Structural characterization of lignin polymers by temperature-resolved in-source pyrolysis - mass spectrometry and Curie-point pyrolysis - gas chromatography/mass spectrometry. J Anal Appl Pyrol 25:149-183

Velásquez JA, Ferrando F, Salvadó J (2003) Effects of kraft lignin addition in the production of binderless fiberboard from steam exploded Miscanthus sinensis. Ind Crop Prod 18:17-23

Velásquez JA, Ferrando F, Salvadó J (2002) Binderless fiberboard from steam exploded Miscanthus sinensis: the effect of a grinding process. Holz Roh Werkst 60:297-302

Windeisen E, Wegener G (2008) Behaviour of lignin during thermal treatments of woods. Ind Crop Prod 27:157-162

Yang H, Yan R, Chen H, Lee DH, Zheng C (2007) Characteristics of hemicellulose, cellulose and lignin pyrolysis. Fuel 86:1781-1788 
Table 1. Percentages of lignin and carbohydrate-related products released from reference wood $($ Ref) and welded material (WM) of sugar maple and yellow birch.

Tabelle 1 Prozentualer Anteil an Lignin- und Kohlenstoffprodukten, die vom ursprünglichen (Ref) und dem verschweißten (WM) Zuckerahorn- und Gelbbirkenholz freigesetzt werden

\begin{tabular}{lcccc}
\hline & \multicolumn{2}{c}{ Sugar maple } & \multicolumn{2}{c}{ Yellow birch } \\
\cline { 2 - 5 } & Ref & $W M$ & Ref & $W M$ \\
\hline \hline$G$ unit & $15.1(0.5)$ & $15.4(1.0)$ & $10.6(0.4)$ & $10.2(1.0)$ \\
$S$ unit & $51.9(2.5)$ & $51.6(2.3)$ & $47.7(3.4)$ & $50.5(4.7)$ \\
$C$ & $33.0(2.7)$ & $33.1(1.6)$ & $41.7(3.4)$ & $39.4(4.8)$ \\
$S / G$ & $3.4(0.2)$ & $3.4(0.4)$ & $4.5(0.4)$ & $5.0(0.7)$ \\
$L / C$ & $2.0(0.3)$ & $2.0(0.1)$ & $1.4(0.2)$ & $1.6(0.3)$ \\
\hline
\end{tabular}

Standard deviation in parentheses; $G$ unit: guaiacyl lignin unit; $S$ unit: syringyl lignin unit; $L$ : lignin; $C$ : carbohydrates. 
Table 2. Lignin-related pyrolysis products (\%) from sugar maple and yellow birch reference wood (Ref) and welded material (WM).

Tabelle 2 Pyrolyseprodukte (\%) des Lignins aus den ursprünglichen (Ref) und dem verschweißten $(W M)$ Zuckerahorn- und Gelbbirkenholz 


\begin{tabular}{|c|c|c|c|c|c|c|c|c|c|}
\hline & \multicolumn{2}{|c|}{ Sugar maple } & \multicolumn{2}{|c|}{ Yellow birch } & & \multicolumn{2}{|c|}{ Sugar maple } & \multicolumn{2}{|c|}{ Yellow birch } \\
\hline & $\operatorname{Ref}$ & $W M$ & Ref & $W M$ & & Ref & $W M$ & Ref & $W M$ \\
\hline G-type derivatives & & & & & S-type derivatives & & & & \\
\hline Guaiacol $^{\mathrm{D}}$ & $1.4^{* \mathrm{a}}$ & $2.2 *$ & 0.7 & 0.6 & Syringol $^{1}$ & $8.1^{*}$ & $10.3^{*}$ & 4.5 & 4.8 \\
\hline 4-Methylguaiacol ${ }^{\mathrm{D}}$ & 2.7 & 2.5 & 1.0 & 0.9 & 4-Methylsyringol ${ }^{\mathrm{I}}$ & $7.7 *$ & $3.9^{*}$ & 0.7 & 0.5 \\
\hline 4-Ethylguaiacol ${ }^{\mathrm{D}}$ & $0.5^{*}$ & $0.8^{*}$ & 0.4 & 0.3 & 4-Ethylsyringol ${ }^{\mathrm{I}}$ & 0.9 & 1.1 & 0.6 & 0.7 \\
\hline 4-Vinylguaiacol ${ }^{\mathrm{D}}$ & 4.4 & 5.0 & 3.5 & 3.0 & 4-Vinylsyringol ${ }^{\mathrm{I}}$ & 17.8 & 16.6 & 15.3 & 15.3 \\
\hline Eugenol $^{\mathrm{D}}$ & $0.9^{*}$ & $0.7 *$ & 0.9 & 0.7 & 4-Allylsyringol ${ }^{\mathrm{I}}$ & 2.8 & 2.8 & 4.0 & 3.8 \\
\hline 4-Propylguaiacol ${ }^{\mathrm{D}}$ & 0.1 & 0.2 & $0.1 *$ & $0.3^{*}$ & 4-Propylsyringol ${ }^{\mathrm{I}}$ & 0.2 & 0.2 & 0.2 & 0.1 \\
\hline Vanillin ${ }^{A}$ & $2.2 *$ & $2.8^{*}$ & 1.8 & 1.6 & Cis-4-propenylsyringol ${ }^{\mathrm{I}}$ & 2.1 & 2.1 & 2.5 & 2.5 \\
\hline Cis-isoeugenol ${ }^{\mathrm{D}}$ & 0.6 & 0.5 & 0.6 & 0.5 & Syringaldehyde $\mathrm{E}^{\mathrm{E}}$ & $6.8^{*}$ & $9.9 *$ & 9.6 & 10.1 \\
\hline Trans-isoeugenol $^{\mathrm{D}}$ & 4.0 & 3.7 & 3.9 & 3.6 & 4-Propynylsyringol ${ }^{\mathrm{I}}$ & 1.7 & 1.8 & $3.0^{*}$ & $3.5^{*}$ \\
\hline Homovanillin $^{\mathrm{A}}$ & 0.8 & 0.9 & 1.2 & 0.9 & 4-Propynylsyringol isomer ${ }^{\mathrm{I}}$ & 0.7 & 0.7 & 1.4 & 1.4 \\
\hline 1-(4-hydroxy-3- & 0.8 & 0.7 & 1.0 & 1.00 & Trans-4-propenylsyringol $^{\mathrm{I}}$ & 17.4 & 17.0 & 23.8 & 24.6 \\
\hline methoxyphenyl) propyne ${ }^{\mathrm{D}}$ & & & & & Acetosyringone $\mathrm{F}$ & 2.6 & 2.7 & 3.1 & 2.8 \\
\hline Acetovanillone ${ }^{\mathrm{B}}$ & 1.2 & 1.2 & $1.4^{*}$ & $1.1^{*}$ & Syringylacetone $\mathrm{F}^{\mathrm{F}}$ & $1.2 *$ & $1.5^{*}$ & $1.1^{*}$ & $1.6^{*}$ \\
\hline Guaiacyl acetone $^{\mathrm{B}}$ & $0.4^{*}$ & $0.5^{*}$ & 0.3 & 0.4 & Syringic acid methyl ester ${ }^{\mathrm{H}}$ & 0.6 & 0.8 & 0.4 & 0.5 \\
\hline \multirow[t]{5}{*}{ Trans-coniferyl alcohol ${ }^{\mathrm{C}}$} & 1.9 & 1.3 & 1.4 & 1.6 & Propiosyringone $\mathrm{F}^{\mathrm{F}}$ & 1.2 & 1.1 & $2.1^{*}$ & $1.4^{*}$ \\
\hline & & & & & Dihydrosinapyl alcohol $^{\mathrm{G}}$ & 0.4 & 0.4 & 0.6 & 0.7 \\
\hline & & & & & Trans-sinapaldehyde $\mathrm{E}^{\mathrm{E}}$ & 3.6 & 4.7 & 5.1 & 7.0 \\
\hline & & & & & Trans-sinapylalcohol $^{\mathrm{G}}$ & 0.3 & 0.6 & $0.7^{*}$ & $1.8^{*}$ \\
\hline & & & & & S-aldehyde ${ }^{\mathrm{E}}$ & $10.4^{*}$ & $14.6^{*}$ & 14.7 & 17.1 \\
\hline G-aldehyde ${ }^{A}$ & $3.0^{*}$ & $3.7^{*}$ & 3.0 & 2.5 & S-ketone $\mathrm{F}^{\mathrm{F}}$ & 5.0 & 5.3 & 6.3 & 5.7 \\
\hline G-ketone ${ }^{B}$ & 1.6 & 1.7 & 1.7 & 1.5 & S-alcohol ${ }^{\mathrm{G}}$ & 0.7 & 1.1 & $1.3^{*}$ & $2.5^{*}$ \\
\hline G-alcohol ${ }^{\mathrm{C}}$ & 1.9 & 1.3 & 1.4 & 1.6 & S-ester ${ }^{\mathrm{H}}$ & 0.6 & 0.8 & 0.4 & 0.5 \\
\hline $\mathrm{Oxy} / \mathrm{Alk}^{(\mathrm{A}+\mathrm{B}+\mathrm{C}) / \mathrm{D}}$ & 0.4 & 0.4 & 0.5 & 0.5 & $\mathrm{Oxy} / \mathrm{Alk}^{(\mathrm{E}+\mathrm{F}+\mathrm{G}+\mathrm{H}) / \mathrm{I}}$ & $0.3^{*}$ & $0.4^{*}$ & 0.4 & 0.5 \\
\hline \multirow[t]{2}{*}{ G- $\mathrm{C}_{6} \mathrm{C}_{1}+\mathrm{C}_{6} \mathrm{C}_{2} / \mathrm{C}_{6} \mathrm{C}_{3}$} & $1.6^{*}$ & $2.0 *$ & 1.4 & 1.2 & S- $\mathrm{C}_{6} \mathrm{C}_{1}+\mathrm{C}_{6} \mathrm{C}_{2} / \mathrm{C}_{6} \mathrm{C}_{3}$ & 1.2 & 1.1 & 0.7 & 0.6 \\
\hline & & & & & G-S- $\mathrm{C}_{6} \mathrm{C}_{1}+\mathrm{C}_{6} \mathrm{C}_{2} / \mathrm{C}_{6} \mathrm{C}_{3}$ & 1.2 & 1.2 & 0.8 & 0.7 \\
\hline
\end{tabular}

$\mathrm{G}$ unit: guaiacyl lignin unit; $\mathrm{S}$ unit: syringyl lignin unit; Oxy/Alk: ratio between lignin-derived compounds containing oxygenated functions (Oxy) in their side chains (aldehydes, ketones, alcohols, and esters) and compounds with alkyl side chains (Alk) only; ${ }^{\text {a }}$ Mean of 3 samples; *significantly different $(\mathrm{p}<0.05)$. 
Table 3. Sample surface analysis of reference wood (Ref) and welded material (WM) for sugar maple and yellow birch obtained by XPS: a) Atomic percentages and oxygen/carbon ratios $(\mathrm{O} / \mathrm{C})$; b) Distribution (Area \%) of carbon components (C1s).

Tabelle 3 Oberflächenanalyse des ursprünglichen (Ref) und des verschweißten $(W M)$ Zuckerahorn- und Gelbbirkenholzes mittels XPS: a) Prozentualer Atomanteil und Verhältnis von Sauerstoff/Karbon (O/C); b) Verteilung (Fläche \%) der Karbonbestandteile (CLs)

\begin{tabular}{lcccc}
\hline & \multicolumn{2}{c}{ Yellow birch } & \multicolumn{2}{c}{ Sugar maple } \\
\cline { 2 - 5 } a) & \multicolumn{1}{c}{ Ref } & $W M$ & Ref & $W M$ \\
\hline \hline O 1s & $18.1^{\mathrm{a}}(3.0)^{\mathrm{b}}$ & $19.5(1.5)$ & $28.7(0.8)$ & $34.8(1.4)$ \\
C 1s & $80.3(3.6)$ & $82.0(3.9)$ & $70.0(1.1)$ & $64.5(1.3)$ \\
Others & $1.6(0.5)$ & $0.7(0.0)$ & $1.3(0.3)$ & $0.7(0.1)$ \\
O/C & $0.23(0.05)$ & $0.24(0.02)$ & $0.41(0.02)$ & $0.54(0.03)$ \\
\hline b) & & & & \\
\hline \hline C1 & $69.9(8.3)$ & $67.3(4.8)$ & $45.2(2.8)$ & $22.1(0.3)$ \\
C2 & $21.5(7.7)$ & $26.9(2.7)$ & $43.0(2.8)$ & $62.8(2.0)$ \\
C3 & $4.5(0.9)$ & $4.5(0.4)$ & $8.4(0.8)$ & $12.1(2.1)$ \\
C4 & $4.1(0.3)$ & $3.7(0.2)$ & $3.4(0.9)$ & $3.0(0.1)$ \\
\hline
\end{tabular}

${ }^{a}$ Mean of 3 samples; ${ }^{b}$ Standard deviation. 
Table 4. Volatile organic compounds of yellow birch identified by Py-GC/MS.

Tabelle 4 Mittels Py-GC/MS bestimmte flüchtige organische Verbindungen von Gelbbirke

\begin{tabular}{lll}
\hline $\begin{array}{l}\text { Retention time } \\
(\mathrm{min})\end{array}$ & Compound & Origin \\
\hline \hline $3.38^{\mathrm{a}}$ & Acetic acid & $\mathrm{H}$ \\
7.15 & Furan-2-carbaldehyde & $\mathrm{H}$ \\
11.86 & 3-methyloxolane-2,4-dione & $\mathrm{H}$ \\
12.82 & 2-pentylfuran, & $\mathrm{H}$ \\
13.60 & 3,4-dihydro-2,5-dimethyl-2H-pyran-2- & $\mathrm{H}$ \\
& methanol & \\
15.10 & 3H-furan-2-one & $\mathrm{H}$ \\
17.01 & 2-methoxyphenol & $\mathrm{L}$ \\
20.28 & 2-methoxy-4-methylphenol & $\mathrm{L}$ \\
23.30 & 4-ethyl-2-methoxy-phenol & $\mathrm{L}$ \\
24.70 & 4-ethenyl-2-methoxyphenol & $\mathrm{L}$ \\
25.77 & 2,6-dimethoxyphenol & $\mathrm{L}$ \\
26.21 & 2-methoxy-4-prop-2-enylphenol & $\mathrm{L}$ \\
27.58 & 4-Hydroxy-3-methoxybenzaldehyde & $\mathrm{L}$ \\
28.96 & 2,6-dimethoxy-4-methylphenol & $\mathrm{L}$ \\
29.17 & Trans-2-methoxy-4-[(E)-prop-1- & $\mathrm{L}$ \\
& enyl]phenol & \\
30.05 & 1-(4 hydroxy-3-methoxy phenyl)allene & $\mathrm{L}$ \\
30.28 & 1-(4-hydroxy-3-methoxyphenyl)ethanone & $\mathrm{L}$ \\
31.39 & 4-ethyl-2,6-dimethoxyphenol & $\mathrm{L}$ \\
32.60 & 4-ethenyl-2,6-dimethoxyphenol & $\mathrm{L}$ \\
35.02 & Cis-2,6-dimethoxy-4-prop-1-enylphenol & $\mathrm{L}$ \\
35.29 & 4-hydroxy-3,5-dimethoxybenzaldehyde & $\mathrm{L}$ \\
35.85 & Trans-2,6-dimethoxy-4-prop-1-enylphenol & $\mathrm{L}$ \\
38.15 & 1-(4-hydroxy-3,5-dimethoxyphenyl)propan- & $\mathrm{L}$ \\
& 2-one & \\
\hline & &
\end{tabular}

${ }^{a}$ Mean of 3 injections; H: hemicelluloses; L: lignin. 
Table 5. Volatile organic compounds of sugar maple identified by Py-GC/MS.

Tabelle 5 Mittels Py-GC/MS bestimmte flüchtige organische Verbindungen von Zuckerahorn

\begin{tabular}{lll}
\hline $\begin{array}{l}\text { Retention time } \\
\text { (min) }\end{array}$ & Compound & Origin \\
\hline \hline $3.62^{\mathrm{a}}$ & Acetic acid & $\mathrm{H}$ \\
7.30 & Furan-2-carbaldehyde & $\mathrm{H}$ \\
10.50 & Furan-2-ylmethanol & $\mathrm{H}$ \\
11.88 & 5-methylfuran-2-carbaldehyde & $\mathrm{H}$ \\
13.77 & 4-hydoxy-5,6-dihydro-2H-pyran-2-one & $\mathrm{H}$ \\
16.70 & 2-methoxyphenol & $\mathrm{L}$ \\
20.36 & 2-methoxy-4-methylphenol & $\mathrm{L}$ \\
21.07 & Unknown & $\mathrm{H}$ \\
24.82 & 4-ethenyl-2-methoxyphenol & $\mathrm{L}$ \\
25.98 & 2,6-dimethoxyphenol & $\mathrm{L}$ \\
26.18 & 2-methoxy-4-prop-2-enylphenol & $\mathrm{L}$ \\
27.66 & 4-hydroxy-3-methoxybenzaldehyde & $\mathrm{L}$ \\
27.77 & Cis-2-methoxy-4-[(E)-prop-1-enyl]phenol & $\mathrm{L}$ \\
29.31 & Trans-2-methoxy-4-[(E)-prop-1- & $\mathrm{L}$ \\
& enyl]phenol & \\
30.15 & 1-(4-hydroxy-3-methoxy phenyl)allene & $\mathrm{L}$ \\
30.32 & 1-(4-hydroxy-3-methoxyphenyl)ethanone & $\mathrm{L}$ \\
32.60 & 4-ethenyl-2,6-dimethoxyphenol & $\mathrm{L}$ \\
35.37 & 4-hydroxy-3,5-dimethoxybenzaldehyde & $\mathrm{L}$ \\
35.87 & 2,6-dimethoxy-4-prop-1-enylphenol & $\mathrm{L}$ \\
36.59 & Trans-2,6-dimethoxy-4-prop-1-enylphenol & $\mathrm{L}$ \\
\hline
\end{tabular}

${ }^{a}$ Mean of 3 injections; H: hemicelluloses; L: lignin. 
Table 6. Volume of non-condensable gases produced during wood-dowel welding determined by Tabelle 6 Mittels GC-FID ermitteltes Volumen der nicht kondensierbaren Gase, die beim Reibschweißen entstehen GC-FID.

\begin{tabular}{lcccc}
\hline GC-FID $(\mathrm{ppm})$ & $\mathrm{CH}_{4}$ & $\mathrm{C}_{2} \mathrm{H}_{4}$ & $\mathrm{C}_{2} \mathrm{H}_{6}$ & $\mathrm{C}_{2} \mathrm{H}_{2}$ \\
\hline \hline Sugar maple & $26.21^{\mathrm{a}}$ & 1.07 & 0.53 & 0.00 \\
& $(0.14)^{\mathrm{b}}$ & $(0.01)$ & $(0.07)$ & $(0.00)$ \\
Yellow birch & 30.51 & 3.45 & 0.95 & 0.00 \\
& $(0.11)$ & $(0.00)$ & $(0.06)$ & $(0.00)$ \\
\hline
\end{tabular}

${ }^{\mathrm{a}}$ Mean of 3 injections; ${ }^{\mathrm{b}}$ Standard deviation. 


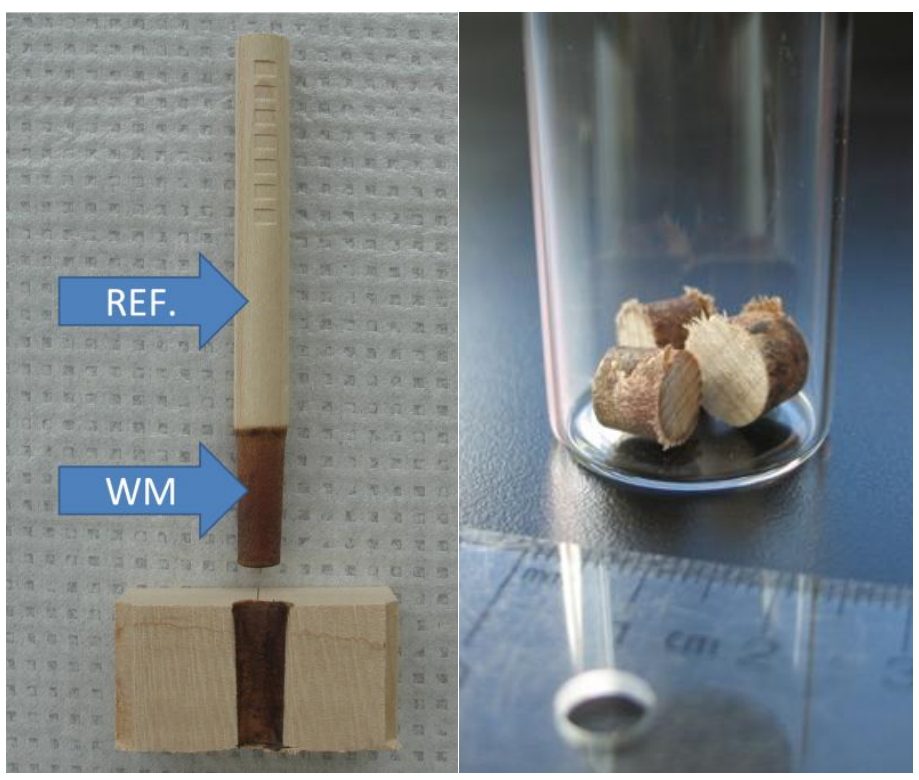

a)

b)

Figure 1. a) Wood-welded dowel and cross-cut section of wood substrate following tensile strength test. The wood reference (Ref) and welded material $(W M)$ were used for the investigation on thermo-chemical modifications occurring at welded interface; b) Prepared samples from a wood-welded dowel for XPS and ATR-FTIR analysis.

Abb. 1 a) Dübel und aufgespaltenes Holzteil einer Reibschweißverbindung nach dem Ausziehversuch. Das ursprüngliche (Ref) und das verschweißte (WM) Holz wurden zur Untersuchung thermochemischer Veränderungen, die auf der Schweißfläche auftreten, verwendet. b) Prüfkörper eines verschweißten Dübels für die XPS- und ATR-FTIR-Analyse 
a)<smiles>COc1cc(C=O)cc(OC)c1OC</smiles>

b)

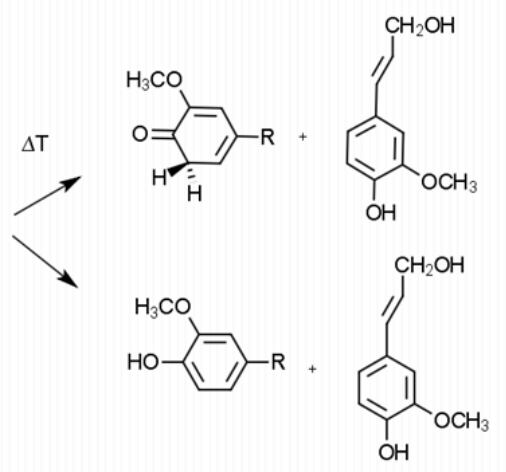

c)
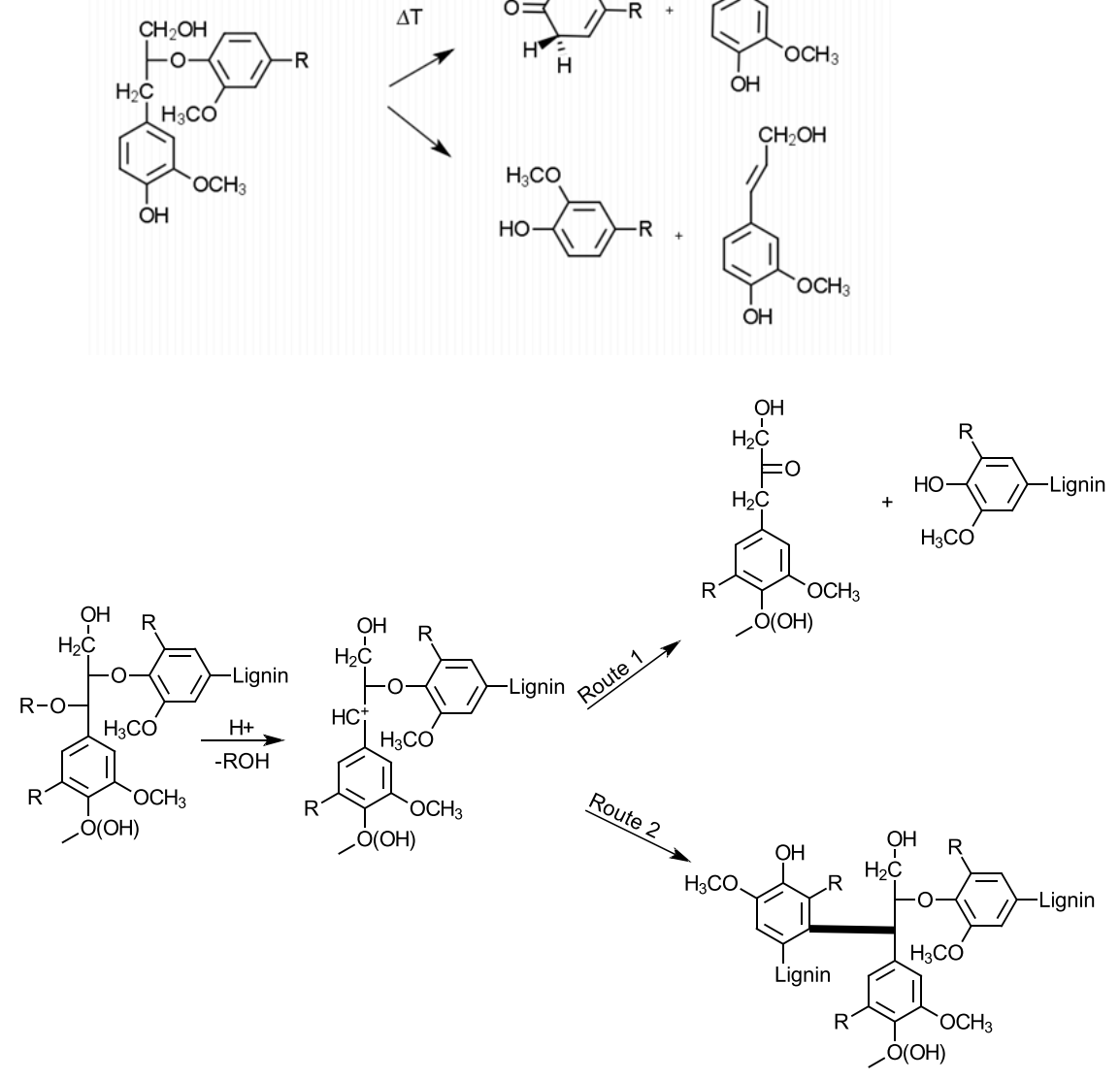

d)

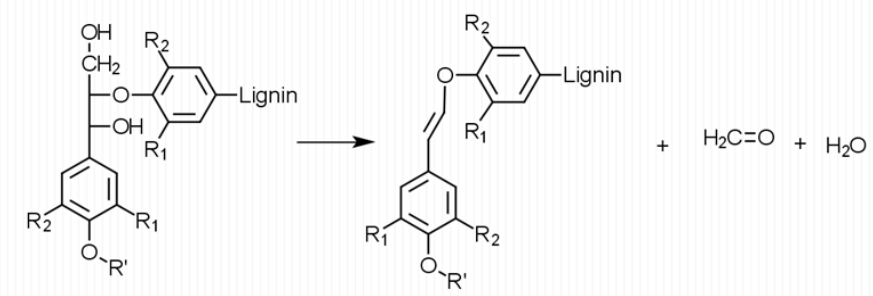

Figure 2. Chemical mechanisms related to wood welding: a) Changes in lignin after side chain oxidation (adapted from Geib et al. 2008); b) Free radical thermal degradation pathways of $\beta$-O4-bonded lignin structures (adapted from van der Hage et al. 1993); c) Depolymerisation (route 1) and condensation (route 2) reactions of lignin ( $\mathrm{Li}$ et al. 2007); d) Formation of formaldehyde from lignin units (adapted from Schäfer and Roffael (2000). 
Abb. 2 Chemische Mechanismen beim Reibschweißen a) Veränderungen im Lignin nach Oxidation der Seitenketten (nach Geib et al. 2008); b) thermischer Abbau der freien Radikale der $\beta$-O-4-gebundenen Ligninstrukturen (nach van der Hage et al. 1993) c) Depolimerisations- (Route 1) und Kondensationsreaktionen (Route 2) von Lignin (Li et al. 2007); d) Bildung von Formaldehyd aus Lignineinheiten (nach Schäfer und Roffael 2000) 